Article

\title{
Positive Aspects of Green Roof Reducing Energy Consumption in Winter
}

Peter Juras (D)

Citation: Juras, P. Positive Aspects of Green Roof Reducing Energy Consumption in Winter. Energies 2022, 15, 1493. https://doi.org/ 10.3390/en15041493

Academic Editors: Francesco Nocera and Tomasz Kisilewicz

Received: 4 January 2022

Accepted: 13 February 2022

Published: 17 February 2022

Publisher's Note: MDPI stays neutral with regard to jurisdictional claims in published maps and institutional affiliations.

Copyright: (C) 2022 by the author. Licensee MDPI, Basel, Switzerland. This article is an open access article distributed under the terms and conditions of the Creative Commons Attribution (CC BY) license (https:// creativecommons.org/licenses/by/ $4.0 /)$.
Department of Building Engineering and Urban Planning, Faculty of Civil Engineering, University of Zilina, Univerzitna 8215/1, 01026 Zilina, Slovakia; peter.juras@uniza.sk

\begin{abstract}
Greening structures attract worldwide attention because of their multidisciplinary benefits. Green roofs are considered one of the best ways to eliminate summer overheating, mitigate climate change, or reduce the urban heat island effect. The winter season and its impact on building energy consumption are often overlooked. Common standards do not take a green roof structure into consideration because of possible high water content in their layers. Additional roof layers may have a positive effect during the winter; they help reduce surface overcooling in cloudless winter nights. This paper analyses experimental measurements taken on two different extensive green roofs and compares the results with a single-ply roof $(\mathrm{R})$ with a PVC membrane. Surface overcooling of the R due to radiation reaching up to $10^{\circ} \mathrm{C}$, whereas the green roof membrane is protected. The influence of thermal loss is not so important for the current climate in Central Europe, as the required U-values are lower than 0.1 . The temperature difference is reduced from $17{ }^{\circ} \mathrm{C}$ on the membrane to $0.7^{\circ} \mathrm{C}$ on the top of the concrete slab. The green roof is still advantageous, and the vegetation surface has better thermal stability. The advantage is clearly recognisable in the area of the condensation zone. The difference between these two extensive green roofs is very small in regard to the accuracy of the temperature sensors. The outcome showed the thermal loss reduction compared to the common flat roof; however, after analysis, it was more marginal than expected.
\end{abstract}

Keywords: green roof; winter; longwave radiation; comparison; measurement; snow

\section{Introduction}

The greenery systems, including mainly green roofs and facades, have a lot of research behind them. They are primarily focused on mitigating climate change, reducing urban heat island intensity, and improving the quality of microclimates around buildings. The Hanging Gardens in Babylon are considered the first green roofs, dating back to around 600 B.C. The riding school in Lipnik nad Becvou had the oldest green roof in former Czechoslovakia. It was constructed in 1911. In 2005, most of its layers were replaced by new ones, but the waterproofing membrane remained as the original. The terraces in Nitra Castle are also among the oldest examples of green roofs in Slovakia.

Green roofs provided protection against adverse meteorological conditions and improved the insulation effects and durability of buildings enveloped in the cold climate of Northern Europe. A rediscovery of this technology took place mostly in Europe (Germany) in the 1960s and 1970s [1]. Green roofs have many benefits, such as a reduction in urban heat island intensity and in summer overheating of interiors, rainwater retention and evapotranspiration, dust particle collection, fire safety, various architectural and aesthetic aspects, etc. Worldwide research efforts can be divided into several fields concerning these benefits: reducing the runoff volumes to the drainage network [2-4], storm water management [4,5], increasing green areas within cities to mitigate the urban heat island (UHI) [6,7], wetting individual surfaces, and more complex simulations of urban environments [8]. Evapotranspiration from vegetation is important because of the dissipating part of surface heat flux converting into latent heat released to the external environment $[9,10]$. It is often increased 
by additional irrigation or watering [11,12], which can enhance cooling potential [10], and it is important for heat waves [13]. Energy savings are mostly represented with a reduction in cooling loads [11,14]. Measurements of individual material properties of layers, such as substrate $[15,16]$ and the quality of runoff water [17], are conducted.

Experimental measurements are conducted on different scales $[18,19]$ with different accents on results, mostly on summer benefits [18-21]. Comparisons with simulations are given in $[18,22,23]$. Winter benefits are the aim of [24-26], but the winter period is not widely covered [1,27]. The presence of snow [28] can highly influence the results and differences between a 'bare' single-ply roof (R) and a green roof (GR). Usual energy saving in winter is $10-15 \%$ [1,29,30], depending highly on the thickness of thermal insulation [29,31,32]. The cooling effect of longwave radiation during winter overcooling of the outer surface is crucial $[26,33,34]$. Measurements of longwave radiation, among other outdoor climate parameters, are important $[35,36]$.

As the references show, the use of a green roof is not a new idea. However, research known to authors in the Central European region and in Slovakia is limited to experimental roofs in Kosice [37]. Similar research focused on more types of green roofs [38] is conducted in the University Centre for Energy Efficient Buildings CTU in Bustehrad in the Czech Republic.

The aim of the conducted research is to identify clear benefits of using an extensive green roof in the Central European climate by considering all the 'pros', such as temperature reduction, water retention, the potential of decreasing the UHI effect, etc. Green roof compositions that are more different are compared, including roofs with an innovative water retention board made from recycled materials in order to maintain circular economy and reduce environmental impacts. The introduction and initial temperature measurement can be found in [39]. Highlighted in this research is the possibility to compare temperature and water retention in one place, although it requires another sample from each GR composition due to the need of using a tipping-bucket rain gauge. To estimate the evapotranspiration, the temperature and relative humidity near the vegetation surface will be measured in the summer.

This paper analyses the results of the winter regime with and without snow in two different extensive green roofs and in one single-ply roof. Research methods, including the experimental test site, are explained in Section 2. The results and discussion are presented in Section 3. The results are showed in temperature courses of the selected periods. Section 4 draws the conclusions and future objectives.

\section{Test Site and Methods}

The measurements were taken on a real single-ply roof that was reconstructed in 2019. The roof is above the building of the Faculty of Civil Engineering. The whole roof structure up to the load-carrying concrete slab was removed. Then, the temperature/humidity sensors Sensirion SHT21 were installed in two places of the structure [39]; therefore, a direct comparison between green roof No. 1 (GR 1) and single-ply roof (R) could be made. The rest of the composition can be compared with surface and membrane temperatures sufficient for extensive green roofs.

The calibration measurements between these two places were conducted prior to the construction of GR1. The results were similar [39,40]. The first compositions were constructed in autumn 2020, and construction continued the following year. Each composition was made twice. The first one was for monitoring the temperatures because it was placed on the original waterproof membrane. The second one was slightly elevated; it had an additional pitched layer to increase the angle and add the possibility of using a tipping-bucket rain gauge for measuring the amount of rainwater. The results from water retention have not been published yet.

Figure 1 shows the examined roof structures with segments GR2, GR1, and R that are compared in this paper. Figure 2 shows the preparation of these segments. 


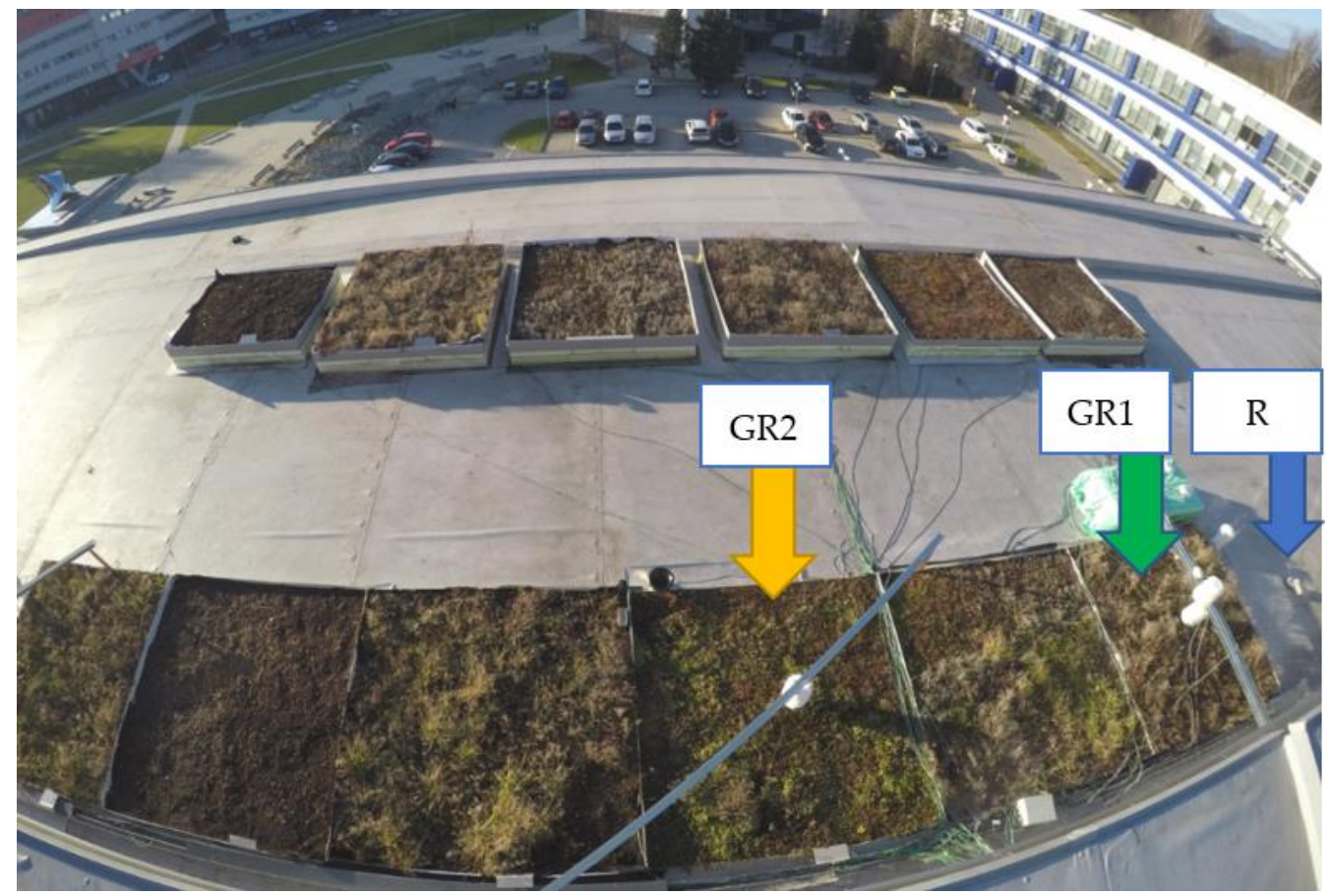

Figure 1. View of the examined green roof structures. The segments compared in this paper are marked with arrows (picture taken in autumn 2021).

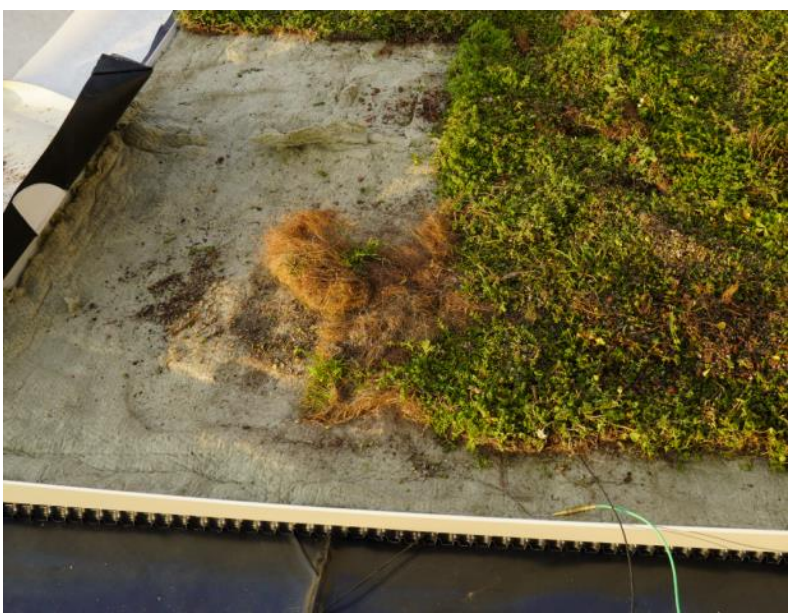

(a)

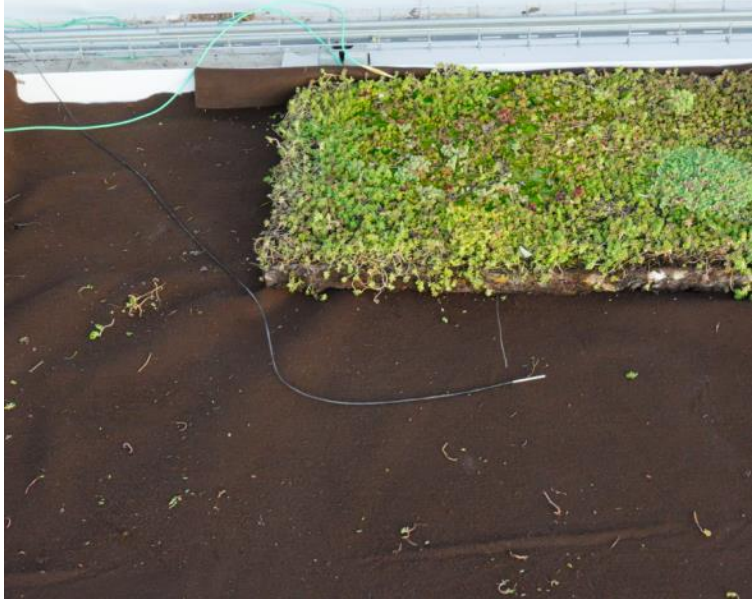

(b)

Figure 2. Two different extensive green roof compositions: (a) GR1 with a prepared vegetation mat on a mineral wool layer, (b) GR2 with a special board with rooted sedum succulents on the top surface, PT100 sensor visible.

Both compared roof compositions are commercially available on the Slovak market and were constructed according to the seller's user guides.

The exact compositions with different special layers are shown in Figure 3 . The structures are $1.8 \times 1.85 \mathrm{~m}$; the measuring position is in the middle. The structures started with the root membrane to avoid the possibility of membrane defects during the conducting of the measurements. The main difference between the compositions was the use of mineral wool substrate and a vegetation mat in GR1, whereas GR2 used a special board made from recycled materials with the ability to plant sedum succulents directly into the board in order to allow the root system of the vegetation to go through the board surface. Features that are more specific will be published later. Figure 3 shows several positions of the sensors used in this comparison. 


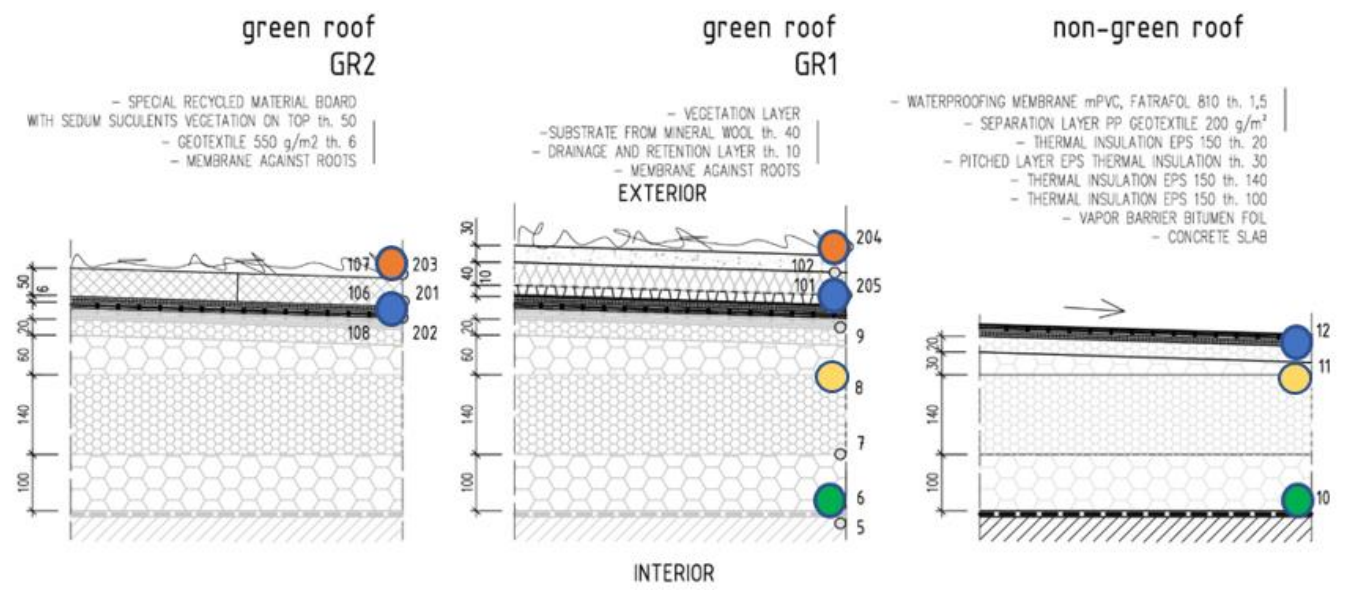

Figure 3. Three roof structures and the positioning of sensors used for the comparison. Particular sensors are marked with circles.

The green roof compositions comprise PT100 sensors and sheathed thermocouples, which are suited for the wet environment (Figure 4). The sensors were connected to the Fluke Hydra data logger with a one-minute recording interval. Sensirion sensors were connected to a Raspberry PI with a one-minute recording interval as well. The outdoor climate was monitored by a weather station situated on the roof of another building within the campus [35-37]. The radiation shields for measuring the temperature above the segments were added in autumn 2021, thus these were not available for this comparison.

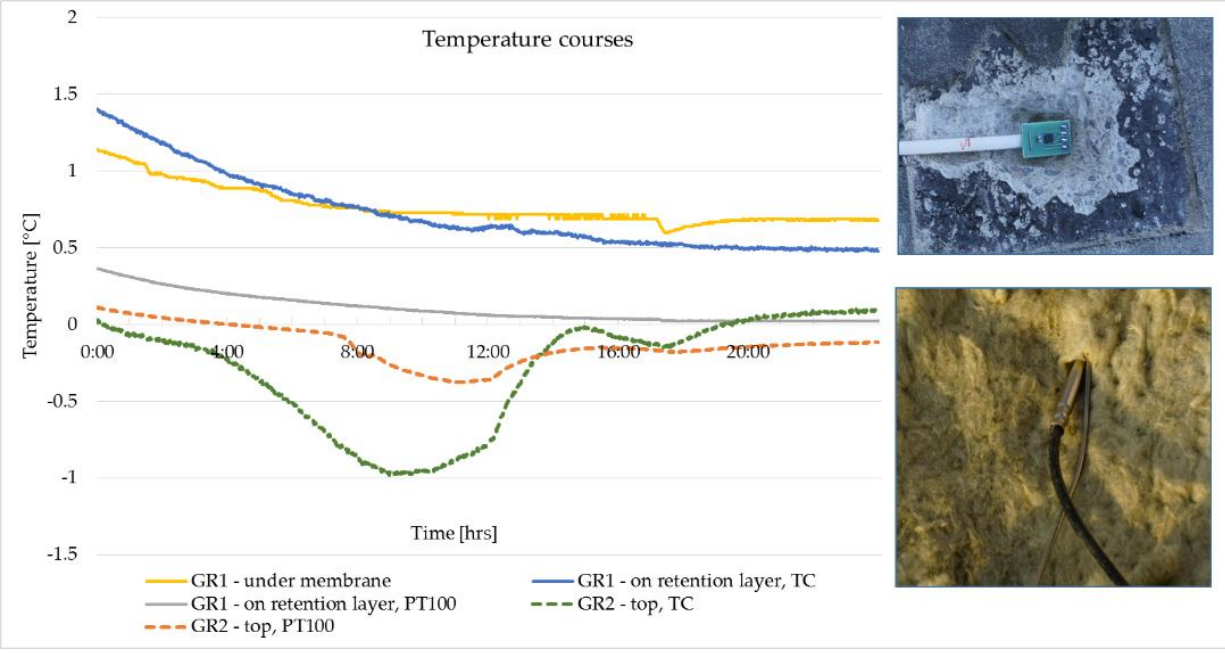

Figure 4. The temperature courses on 27 December 2020 and the comparison of different types of sensors in the same location (dashed lines together, continuous together). Pictures of sensors: SHT21 (top), PT100 (bottom) and sheathed thermocouple.

Figure 4 compares the measured values of the different types of sensors (sheathed thermocouples, PT100s and combined temperature/relative humidity sensors) purposely placed in the same location. The thermocouples had lower stability, so they reacted more rapidly to temperature changes. Unfortunately, the length of the sheath (1 m was used) may have influenced the temperature measured on the top of the vegetation where it was not covered completely by plants or substrate. The differences among the sensors were small, and the shapes of the courses were almost the same.

The roof compositions and positioning of sensors within the structure are shown in Figure 3. Sensors used in this comparison are marked. 


\section{Results and Discussion}

The comparison of the individual structures took place in four periods to provide a sufficient result that the concept was working. Figure 5 presents the whole analyzed period from 21 December 2020 to 19 January 2021; individual parts such as a clear sky, freezing, clouds, and snow presence are marked. The best way to distinguish the boundary conditions is to see the match among the selected three courses, as shown in Figure 5. If the surface temperatures are close to each other and higher than the air temperature, there is snow. If the air temperature is close to the uncovered membrane, the sky is cloudy without sky radiation, etc. The following figures illustrate the results from four shorter analysed periods. Figure 6 shows the roof without snow, with a clear night sky and a cloudy evening (one day). Figure 7 shows the temperature courses for three days. The second day is a typical representative of the clear night sky, when the temperature on the non-protected roof membrane $(\mathrm{R})$ is much lower than the outdoor air temperature.

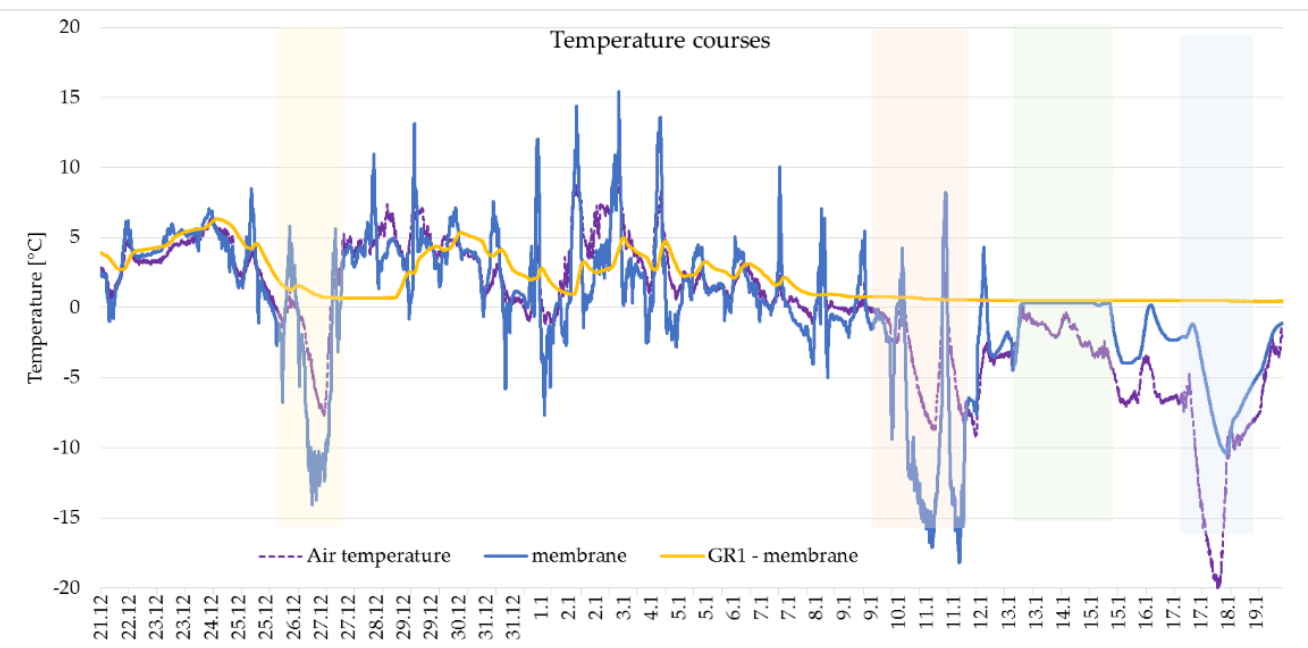

Date

Figure 5. The temperature courses for the whole analysed period from 21 December 2020 to 19 January 2021 and four typical periods marked for a closer look. Temperature courses

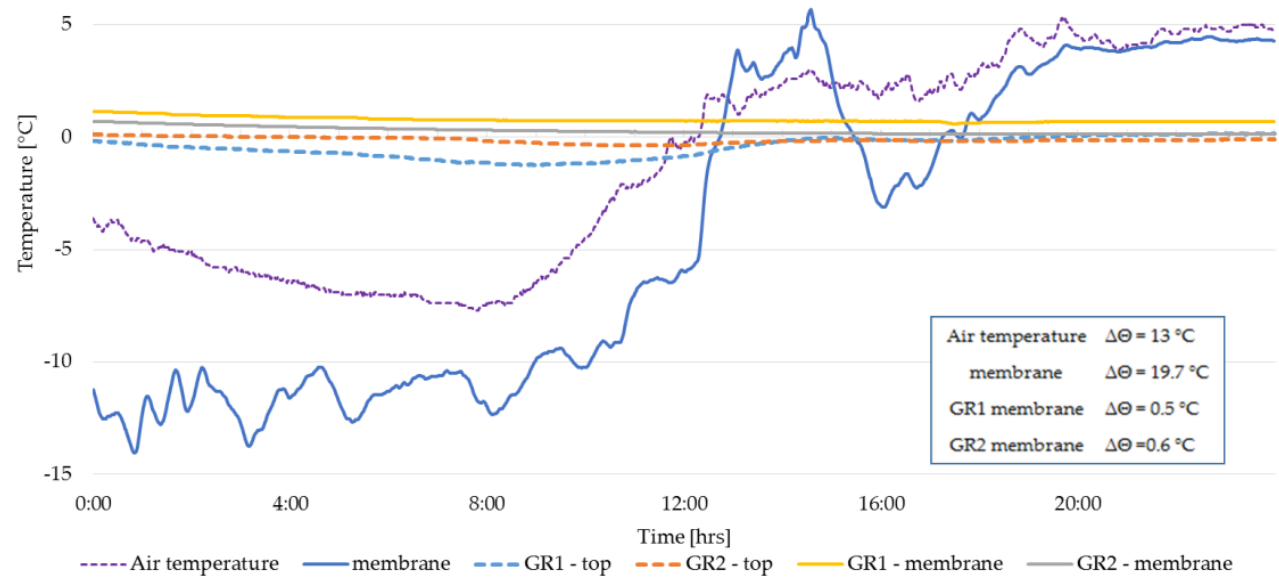

Figure 6. The temperature courses on 27 December 2020. The sky was clear in the night, and the evening and night were cloudy. No snow on the roof; daily amplitude of temperatures $(\Delta \theta)$ for the analysed position in both green roofs has similar and almost constant results. 


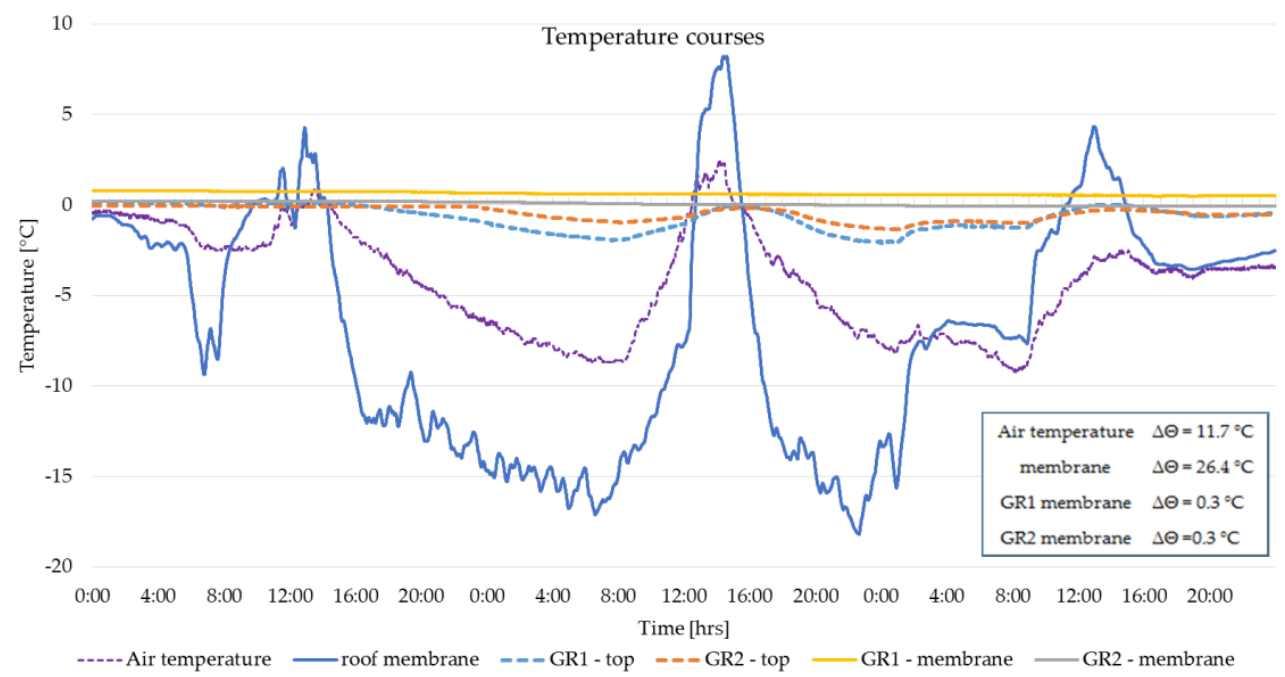

Figure 7. The temperature courses from 10 to 12 January 2021. The first night sky was clear. The second one was somewhat cloudy. There was very high overcooling of the non-covered membrane. No snow on the roof, both green roofs have similar and almost constant results.

Figure 8 shows the longwave radiation measured with a pyrgeometer located in the weather station and the temperature on the membrane of roof R. Figure 9 shows the temperature on the membrane of GR1, where a heat flux plate is located. Figure 10 shows that the high temperature amplitude among the thermal insulation layers is still visible in the $\mathrm{R}$ roof, which was under $50 \mathrm{~mm}$ thick polystyrene board. The temperature courses on the top of the concrete load-carrying slab are shown in Figure 11.

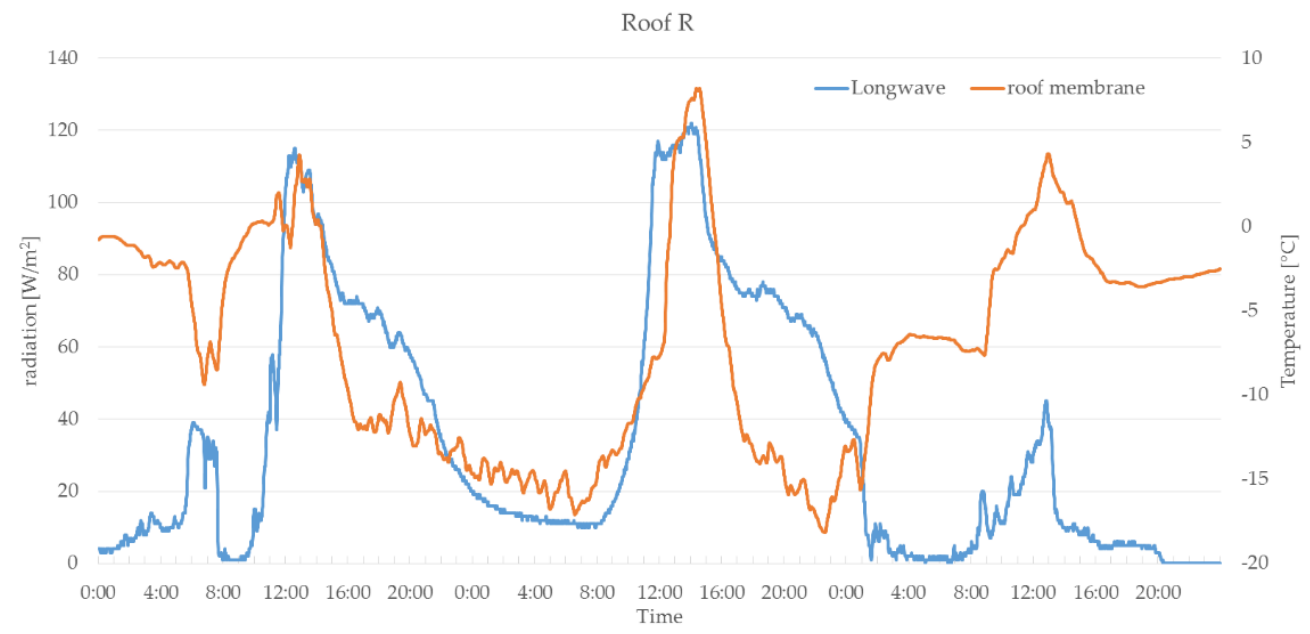

Figure 8. The membrane temperature (R) and longwave radiation courses from 10 to 12 January 2021. 
GR 1

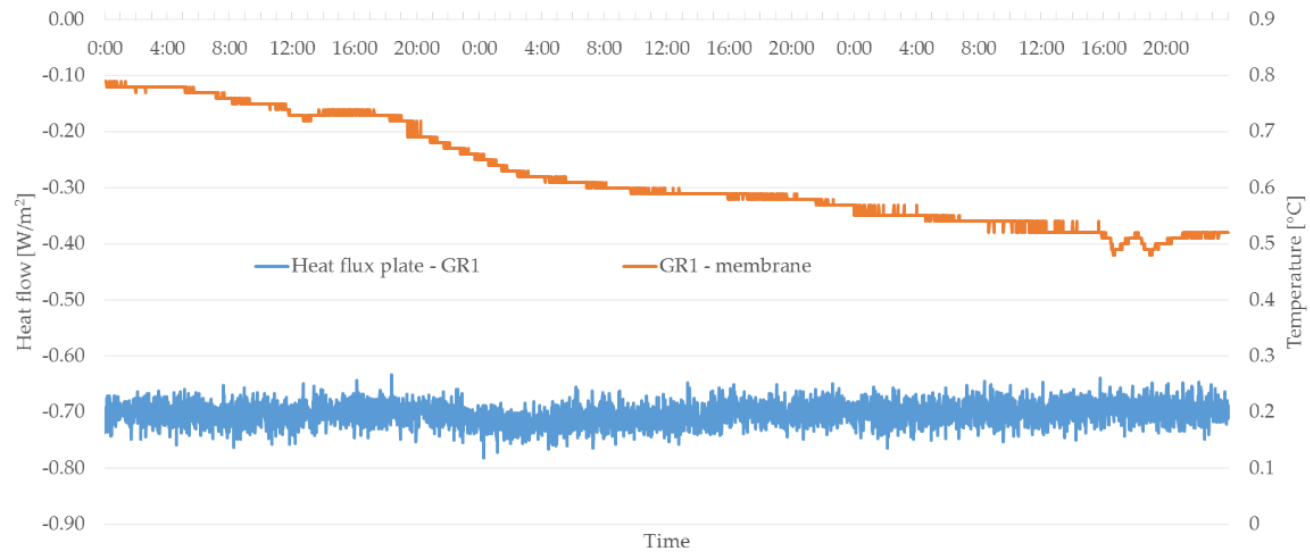

Figure 9. Heat flux and temperature courses from 10 to 12 January 2021, positioned on the membrane.

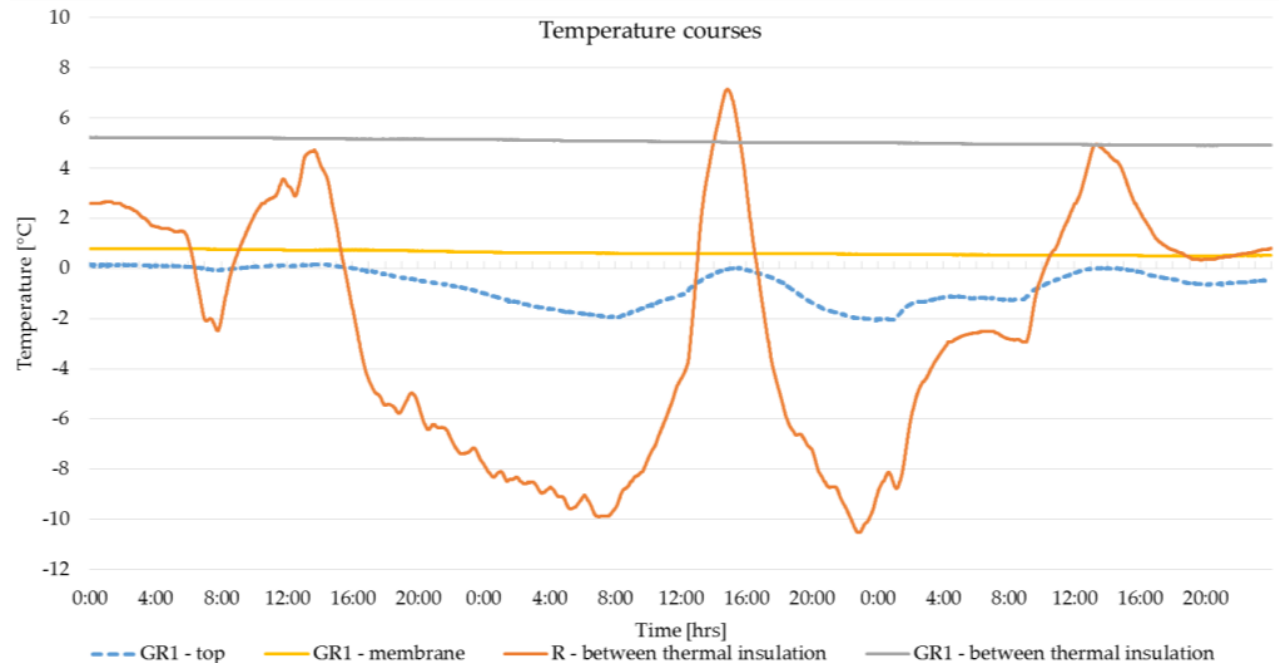

Figure 10. The temperature courses from 10 to 12 January 2021. The temperature inside the roof: the comparison of GR1 and regular flat roof R. The position between thermal insulation was approx. $50 \mathrm{~mm}$ downwards from the top (Figure 3).

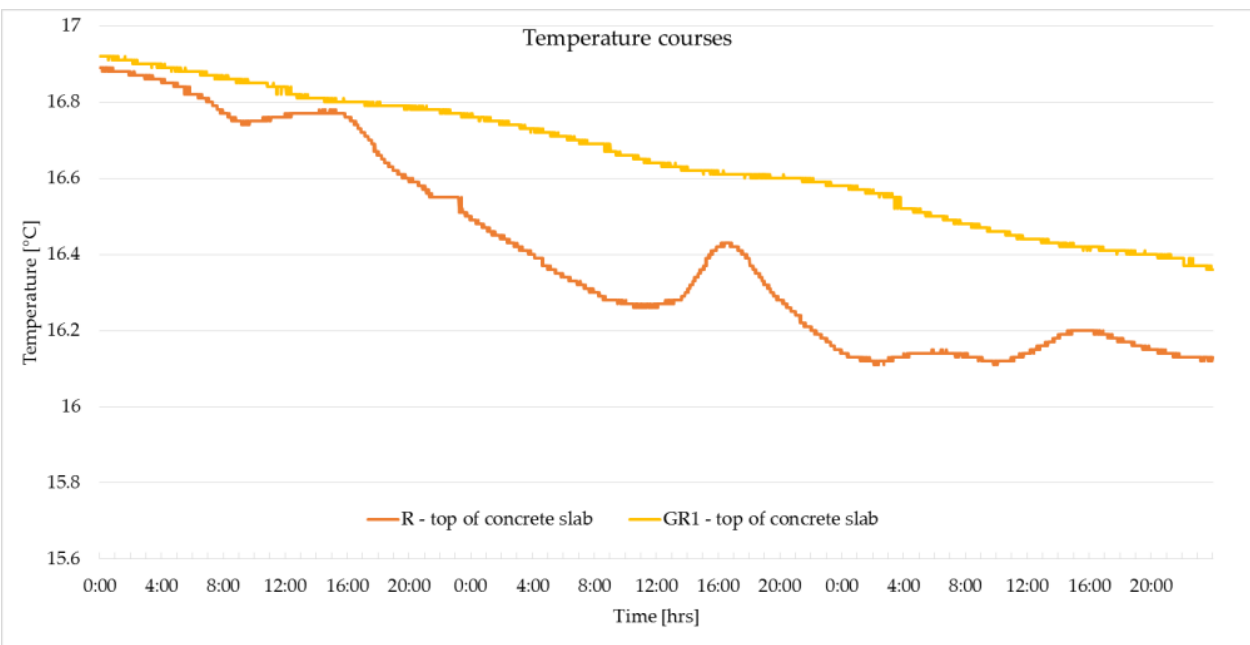

Figure 11. The temperature courses from 10 to 12 January 2021. The temperature inside the roof: the comparison of GR1 and regular flat roof R. The position on the upper surface of the concrete slab (Figure 3). 
Figure 12 shows the temperature courses during the 3-day period when it started snowing, and it ended with a layer about $80 \mathrm{~mm}$ thick. Figure 13 shows the temperature courses for the 3 days again when sunny weather with the clear sky came after snowing. The snow layer protected the surface of the $\mathrm{R}$ roof, and the membrane temperature was higher than the outdoor air. Table 1 summarizes the differences measured (minimum, maximum and average) for the individual and whole periods for the measured/analysed places.

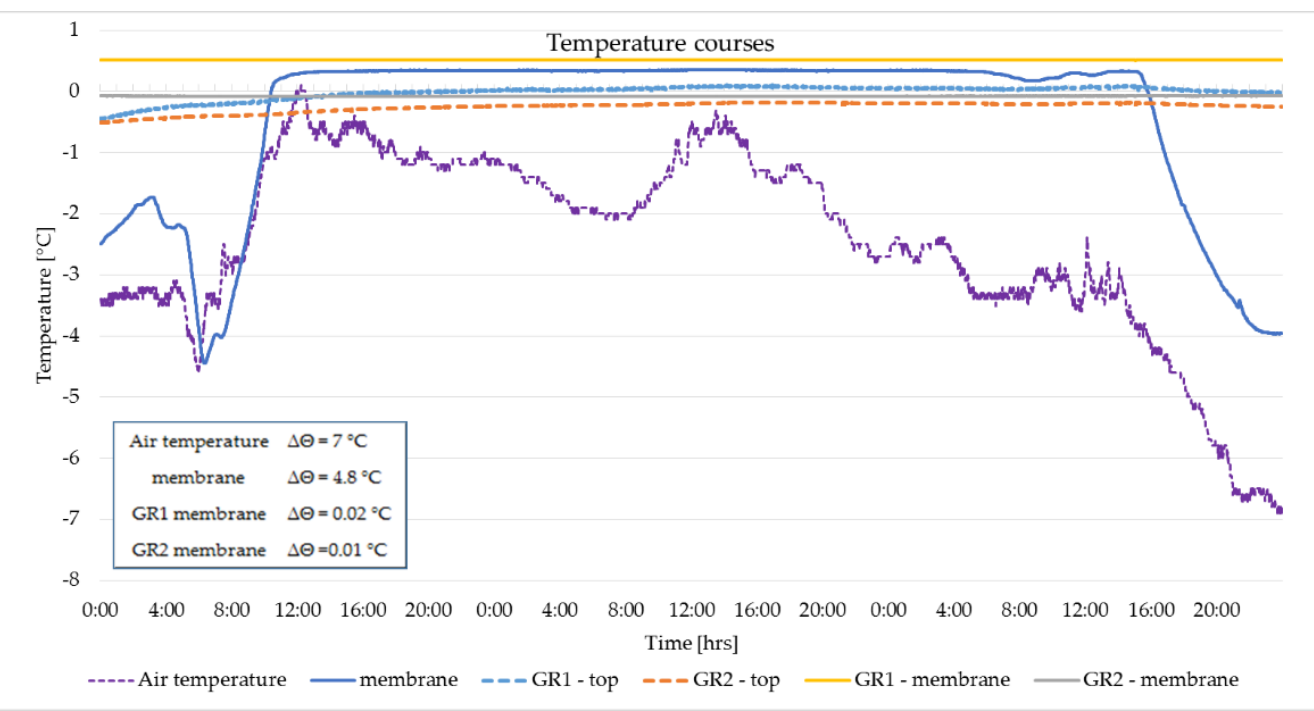

Figure 12. The temperature courses from 13 to 15 January 2021. It was snowing at the beginning, and the roof was later covered with an $80 \mathrm{~mm}$ thick layer of snow. All measured temperatures were higher than the air temperature. Again, both green roofs have similar and almost constant results.

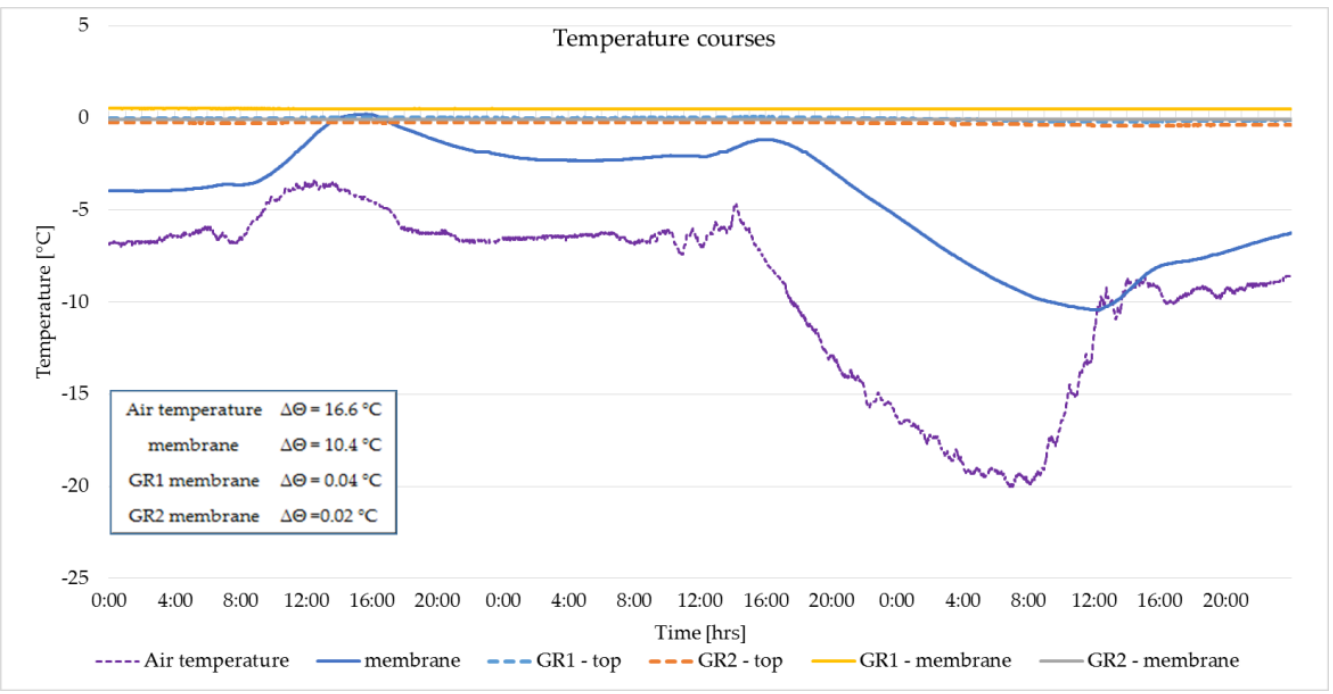

Figure 13. The temperature courses from 16 to 18 January 2021. The roof was still covered with snow. Phase shift caused by the snow layer on the non-covered roof membrane is visible. Both green roofs have similar and almost constant results. 
Table 1. The temperatures measured for analysed periods in the selected positions.

\begin{tabular}{|c|c|c|c|c|}
\hline 21 December-19 January 2021 & Min & Max & Average & $\Delta \Theta\left({ }^{\circ} \mathrm{C}\right)$ \\
\hline Air temperature & -20 & 9.4 & -0.1 & 29.4 \\
\hline membrane & -18.18 & 15.46 & 0.05 & 33.64 \\
\hline GR1 top & -2.06 & 6.41 & 1.41 & 8.47 \\
\hline GR2 top & -1.34 & 5.7 & 1.31 & 7.04 \\
\hline GR1 membrane & 0.47 & 6.35 & 2.05 & 5.88 \\
\hline GR2 membrane & -0.1 & 5.83 & 1.46 & 5.93 \\
\hline slab R & 15.42 & 20.03 & 17.63 & 4.61 \\
\hline slab GR & 15.7 & 20.46 & 17.77 & 4.76 \\
\hline \multicolumn{5}{|l|}{27 December 2020} \\
\hline Air temperature & -7.7 & 5.3 & -1.13 & 13 \\
\hline membrane & -14.06 & 5.67 & -4.35 & 19.73 \\
\hline GR1 top & -1.24 & 0.15 & -0.45 & 1.39 \\
\hline GR2 top & -0.4 & 0.1 & -0.13 & 0.5 \\
\hline GR1 membrane & 0.6 & 1.14 & 0.77 & 0.54 \\
\hline GR2 membrane & 0.14 & 0.7 & 0.27 & 0.56 \\
\hline \multicolumn{5}{|l|}{ 10-12 January 2021} \\
\hline Air temperature & -9.2 & 2.5 & -4.19 & 11.7 \\
\hline membrane & -18.18 & 8.23 & -6.85 & 26.41 \\
\hline GR1 top & -2.06 & 0.16 & -0.69 & 2.22 \\
\hline GR2 top & -1.35 & -0.05 & -0.47 & 1.29 \\
\hline GR1 membrane & 0.48 & 0.79 & 0.62 & 0.31 \\
\hline GR2 membrane & -0.08 & 0.21 & 0.06 & 0.29 \\
\hline \multicolumn{5}{|l|}{ 13-15 January 2021} \\
\hline Air temperature & -6.9 & 0.1 & -2.44 & 7 \\
\hline membrane & -4.44 & 0.35 & -0.43 & 4.79 \\
\hline GR1 top & -0.45 & 0.11 & -0.02 & 0.56 \\
\hline GR2 top & -0.51 & -0.18 & -0.26 & 0.33 \\
\hline GR1 membrane & 0.5 & 0.52 & 0.51 & 0.02 \\
\hline GR2 membrane & -0.08 & -0.07 & -0.08 & 0.01 \\
\hline \multicolumn{5}{|l|}{ 16-18 January 2021} \\
\hline Air temperature & -20.00 & -3.40 & -4.25 & 16.60 \\
\hline membrane & -10.00 & 0.35 & -0.43 & 10.35 \\
\hline GR1 top & -0.22 & 0.06 & -0.52 & 0.28 \\
\hline GR2 top & -0.41 & -0.22 & -0.29 & 0.19 \\
\hline GR1 membrane & 0.47 & 0.51 & 0.49 & 0.04 \\
\hline GR2 membrane & -0.09 & -0.07 & -0.08 & 0.02 \\
\hline
\end{tabular}

\subsection{Green Roof Impact on Temperature Courses}

The chosen period started with decreasing air temperature (see Figure 5). The daily amplitudes were also visible in the green roof in the beginning. If the outdoor air was cold for a longer period, the GR substrate lost its thermal inertia, and after approx. 8 January the temperature was almost constant just above or around $0{ }^{\circ} \mathrm{C}$.

The best influence on the additional layers of green roofs can be evident when taking a closer look at the surface and membrane temperatures shown in Figures 6, 7,12 and 13. The temperature of the membrane in both green roofs is near $0^{\circ} \mathrm{C}$ in all scenarios. This puts the membrane at an almost constant temperature, protects it against $\mathrm{UV}$ radiation, and extends its lifetime significantly. The difference between minimal and maximal temperatures is $6{ }^{\circ} \mathrm{C}$ in both green roofs (average is between $1-2{ }^{\circ} \mathrm{C}$ ) during the whole analysed time period, as can be seen in Table 1 . The difference in roof $\mathrm{R}$ is $33^{\circ} \mathrm{C}$.

The differences between the green roof and the regular single-ply flat roof are very significant. The biggest difference is on the top, but the total thickness of the thermal insulation moves the amplitudes lower and lower. The difference is more significant in the poorly insulated roof in terms of thermal loss at a non-steady state. This is a confirmation of findings made by Daouas [32] that the thicker the insulation is, the less that the heat flows. 
The representatives are the temperature courses on the top of the slabs (see Figure 11), where the difference is minimal and where both have a decreasing tendency. The simple calculations of the steady state are to be published in the future. The problem could be vapor condensation in roof $R$, if the suitable insulation is not used (i.e., deterioration by high moisture content). The analysis of this problem is to be performed using HAM simulation in the future.

The high daily amplitudes also influence the non-protected membrane during the winter period and have a negative effect on its durability. If the temperature drops in both green roofs, it remains almost constant during this time, so it could be stated that the daily amplitudes do not influence the temperature at all. This finding supports the results by Yang et al. [22] and summaries in [1].

\subsection{Differences between Green Roofs}

The differences between green roofs GR1 and GR2 are marginal during the winter period, and they are almost within the sensor accuracy. A different approach results in a smaller total thickness of composition GR2 but has very similar results to that of GR1, which has a possibly wet, $40 \mathrm{~mm}$ mineral wool substrate; therefore, the thermal conductivity is lower than the design value. The thermal conductivity of the recycled board is lower than the design value, but it works as great thermal insulation and increases the temperature of the membrane. Thermal loss is reduced in both cases.

\subsection{Longwave Radiation and Snow Impact}

The temperature courses (see Figures 7-11) for the clear night sky without snow show the impact of the overcooled non-covered surface. The night overcooling caused by longwave radiation and its impact on the membrane of roof $\mathrm{R}$ is visible at around 2:00 a.m. (see Figure 8). The clouds cause the radiation to drop down. The surface temperature rises quickly from -15 up to -7 , and then the surface temperature course copies the outdoor air temperature (see Figure 7). An example of high night overcooling can be seen in Figure 6, where the difference between the membrane and air temperature is up to $6.4{ }^{\circ} \mathrm{C}$, and in Figure 7 up to $10^{\circ} \mathrm{C}$ (air $-8.2^{\circ} \mathrm{C}$ and membrane -18.2 ).

The position in depth of approx. $50 \mathrm{~mm}$ under the non-covered membrane (R) had a daily amplitude of $17^{\circ} \mathrm{C}$, whereas the almost same depth in GR1 had an almost constant course. As the roof had good insulation, the amplitudes for the positions on the top of the slab are very similar (see Figure 11). The single-ply roof also shows some daily amplitudes here, but both GR1 and R have a descending course.

In the cases with snow, the difference is even smaller because snow works as a protective layer. The impact of snow is clear from the courses shown in Figures 12 and 13. The snow layer insulates the surface of roof $\mathrm{R}$ and protects it against overcooling. The phase shift between the outdoor air and the membrane peaks is also visible, and it is about $2 \mathrm{~h}$. The effect of snow is not visible from the temperatures of the membranes in the GRs, but the surfaces of the vegetation heat up a little (start of snowing in Figure 12). As mentioned before, the snow layer protects the non-covered membrane of roof $\mathrm{R}$, and the difference between the air and membrane temperatures reaches up to $9.4{ }^{\circ} \mathrm{C}$ (Figure 13).

\subsection{Correlation Coefficient}

In order to confirm the visual results from temperature courses, the correlation coefficient (CC) was calculated between the air temperature and the temperature on the membrane for roofs R, GR1, and GR2. During the winter, there were more sensors on the exact location in GR2, so there were more temperatures measured, as can be seen, for example, in Figure 4. The correlation coefficient (CC) was calculated using Matlab software with the function xcorr, which returns the cross-correlation of two time series.

Summarized coefficients for the analyzed periods are in Table 2. 
Table 2. Correlation for selected measurement periods, the individual roof, and green roofs.

\begin{tabular}{cccccc}
\hline & Roof R & GR1 & GR2 & GR2A & GR2B \\
\hline 11 January, Figure 7 & $1.39 \times 10^{5}$ & $-5.83 \times 10^{3}$ & $-8.33 \times 10^{2}$ & $-2.15 \times 10^{3}$ & $-2.77 \times 10^{3}$ \\
normalized & 2.16 & -0.09 & -0.01 & -0.03 & -0.04 \\
\hline 29 December, Figure 5 & $2.70 \times 10^{4}$ & $2.86 \times 10^{4}$ & $2.35 \times 10^{4}$ & $2.42 \times 10^{4}$ & $2.42 \times 10^{4}$ \\
normalized & 0.42 & 0.44 & 0.36 & 0.38 & 0.38 \\
\hline 14 January, Figure 12 & 0.478 & -0.153 & 0.0224 & -0.0205307 & -0.0363826 \\
normalized & 0.00 & 0.00 & 0.00 & 0.00 & 0.00 \\
\hline 16-17 January, Figure 13 & $2.18 \times 10^{5}$ & $-1.96 \times 10^{4}$ & $3.22 \times 10^{3}$ & $-2.82 \times 10^{3}$ & $-5.35 \times 10^{3}$ \\
normalized & 3.38 & -0.30 & 0.05 & -0.04 & -0.08 \\
\hline
\end{tabular}

The normalized value is calculated to compare the individual roofs together. The results show that the normalized correlation coefficients for both green roofs are close to 0 for days with freezing and cold weather. This confirms the previous statement that the outdoor air does not influence the membrane temperature. One exception is 29 December. On the day before, the membrane temperature fell to zero and was almost constant (Figure 5). Another example is a normalized CC for roof R on 11 January when the non-protected roof surface was highly overcooled.

Multiple sensors on the membrane in GR2 have very similar results.

\subsection{Histogram for Membrane Temperatures}

The increase in the temperature stability of the waterproofing membrane is shown in Figure 14. This histogram represents the amount of time spent at a certain temperature. During the whole time period, the temperature for GR1 was not lower than $0{ }^{\circ} \mathrm{C}$. For GR2, there are roughly $192 \mathrm{~h}$ in the bin spent ranging from -5 to $0^{\circ} \mathrm{C}$, but a closer look shows that the lowest temperature is $-0.2{ }^{\circ} \mathrm{C}$. The basic difference between these two roofs is caused by the position of the sensor, which is below the membrane in GR1 and above the membrane in GR2.

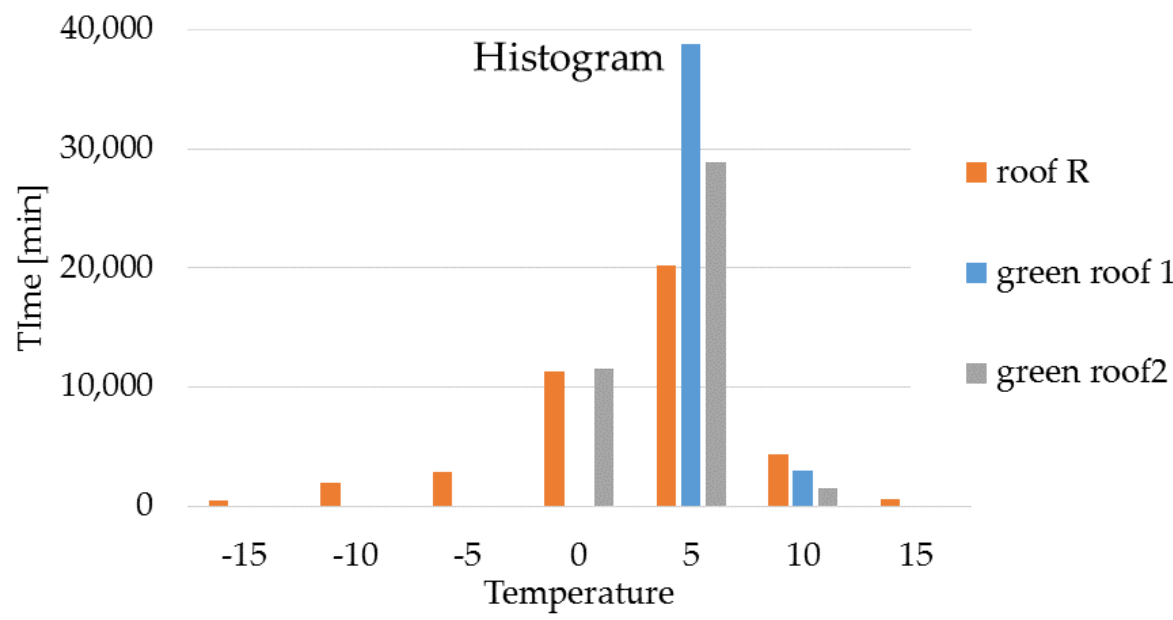

Figure 14. Histogram for membrane temperatures of analysed roofs. Temperatures of the GR membranes are more steady and higher than $0{ }^{\circ} \mathrm{C}$. Membrane of roof R spent almost $20 \%$ of the time below $0{ }^{\circ} \mathrm{C}$.

\section{Conclusions}

This paper is focused on examining experimental green roof compositions and their outcomes during the winter season based on an analysis of a one-month period. The outcomes can be summarized in the following bullet points:

- The existence of the green roof above the waterproofing membrane increases the temperatures of the membranes significantly; 
- The temperatures of the membranes are almost the same in both analysed green roofs.

- The temperature of the vegetation is much higher than that of the surface of the regular roof.

- The green roof decreases the thermal loss of the roof as additional insulation and protects the surface against overcooling.

- $\quad$ The single-ply flat roof R suffers from overcooling of its outer surface (up to $10{ }^{\circ} \mathrm{C}$ in one case), which is also visible within the structure.

Both extensive green roofs have very similar results in terms of temperature courses. If the air temperature drops, that of the green roofs remains almost constant during this time. It could be stated that the daily amplitudes do not influence the temperature at all. The measurement of the heat flux on the membrane also supports the temperature measurement. It could be stated that the green roof also has a positive effect on the thermal regime during the winter season.

The waterproofing membrane, which is vulnerable against low temperatures and UV radiation, is well protected (the exception is another load created by the roots of plants).

Both green roofs constructed in autumn work. The plants survived the winter season, although it is not easy for newly planted vegetation to survive the winter. The overcooling of the outer surface of the regular flat roof $\mathrm{R}$ is significant (up to $6{ }^{\circ} \mathrm{C}$ ), but it does not pose problems in well-insulated structures. It can be more important in poorly insulated roofs not only due to the increased thermal loss but also due to condensation problems. The green roof has a lower thermal loss, and the overcooling has an impact; however, this issue is to be analyzed using HAM simulation in future work.

This future work is focused on examining and comparing the segments as well as the other row of samples constructed primarily for rainwater uptake. There is less shade from the elevated part of another roof in the morning, and the existence of another layer of thermal insulation is to be analyzed.

Funding: This research was funded by Slovak Scientific Grant Agency (VEGA) grant number $1 / 0673 / 20$.

Institutional Review Board Statement: Not applicable.

Informed Consent Statement: Not applicable.

Data Availability Statement: The data presented in this study are available on request from the corresponding author.

Acknowledgments: The research is supported by the grant project VEGA No. 1/0673/20.

Conflicts of Interest: The author declare no conflict of interest. The funders had no role in the design of the study; in the collection, analysis, or interpretation of data; in the writing of the manuscript; or in the decision to publish the results.

\section{References}

1. Bevilacqua, P. The effectiveness of green roofs in reducing building energy consumptions across different climates. A summary of literature results. Renew. Sustain. Energy Rev. 2021, 151, 111. [CrossRef]

2. Palermo, S.A.; Turco, M.; Principato, F.; Piro, P. Hydrological effectiveness of an extensive green roof in Mediterranean climate. Water 2019, 11, 1378. [CrossRef]

3. Talebi, A.; Bagg, S.; Sleep, B.E.; O'Carroll, D.M. Water retention performance of green roof technology: A comparison of canadian climates. Ecol. Eng. 2019, 126, 1-15. [CrossRef]

4. Zhang, S.; Lin, Z.; Zhang, S.; Ge, D. Stormwater retention and detention performance of green roofs with different substrates: Observational data and hydrological simulations. J. Environ. Manag. 2021, 291, 112682. [CrossRef] [PubMed]

5. Carpenter, C.M.; Todorov, D.; Driscoll, C.T.; Montesdeoca, M. Water quantity and quality response of a green roof to storm events: Experimental and monitoring observations. Environ. Pollut. 2016, 218, 664-672. [CrossRef] [PubMed]

6. Wang, Y.; Akbari, H. Analysis of urban heat island phenomenon and mitigation solutions evaluation for Montreal. Sustain. Cities Soc. 2016, 26, 438-446. [CrossRef]

7. Gülten, A.; Aksoy, U.T.; Öztop, H.F. Influence of trees on heat island potential in an urban canyon. Sustain. Cities Soc. 2016, 26, 407-418. [CrossRef] 
8. Kubilay, A.; Allegrini, J.; Strebel, D.; Zhao, Y.; Derome, D.; Carmeliet, J. Advancement in Urban Climate Modelling at Local Scale: Urban Heat Island Mitigation and Building Cooling Demand. Atmosphere 2020, 11, 1313. [CrossRef]

9. Schweitzer, O.; Erell, E. Evaluation of the energy performance and irrigation requirements of extensive green roofs in a waterscarce Mediterranean climate. Energy Build. 2014, 68, 25-32. [CrossRef]

10. Cascone, S.; Coma, J.; Gagliano, A.; Pérez, G. The evapotranspiration process in green roofs: A review. Build. Environ. 2019, 147, 337-355. [CrossRef]

11. Sun, T.; Bou-Zeid, E.; Ni, G.-H. To irrigate or not to irrigate: Analysis of green roof performance via a vertically-resolved hygrothermal model. Build. Environ. 2014, 73, 127-137. [CrossRef]

12. Ascione, F.; Bianco, N.; DE Rossi, F.; Turni, G.; Vanoli, G.P. Green roofs in European climates. Are effective solutions for the energy savings in air-conditioning? Appl. Energy 2013, 104, 845-859. [CrossRef]

13. Heusinger, J.; Weber, S. Surface energy balance of an extensive green roof as quantified by full year eddy-covariance measurements Sci. Total Environ. 2017, 577, 220-230. [CrossRef] [PubMed]

14. Fantozzi, F.; Bibbiani, C.; Gargari, C.; Rugani, R.; Salvadori, G. Do green roofs really provide significant energy saving in a Mediterranean climate? Critical evaluation based on different case studies. Front. Arch. Res. 2021, 10, 447-465. [CrossRef]

15. Ouldboukhitine, S.-E.; Belarbi, R.; Djedjig, R. Characterization of green roof components: Measurements of thermal and hydrological properties. Build. Environ. 2012, 56, 78-85. [CrossRef]

16. Pianella, A.; Clarke, R.E.; Williams, N.S.; Chen, Z.; Aye, L. Steady-state and transient thermal measurements of green roof substrates. Energy Build. 2016, 131, 123-131. [CrossRef]

17. Malcolm, E.G.; Reese, M.L.; Schaus, M.H.; Ozmon, I.M.; Tran, L.M. Measurements of nutrients and mercury in green roof and gravel roof runoff. Ecol. Eng. 2014, 73, 705-712. [CrossRef]

18. Stöckl, B.; Zirkelbach, D.; Künzel, H.M. Hygrothermal Simulation of Green Roofs-New Models and Practical Application. In Proceedings of the 10th Nordic Symposium, Lund, Sweden, 15-19 June 2014.

19. Smalls-Mantey, L.; Montalto, F. The seasonal microclimate trends of a large scale extensive green roof. Build. Environ. 2021, 197, 107792. [CrossRef]

20. Ávila-Hernández, A.; Simá, E.; Xamán, J.; Hernández-Pérez, I.; Téllez-Velázquez, E.; Chagolla-Aranda, M. Test box experiment and simulations of a green-roof: Thermal and energy performance of a residential building standard for Mexico. Energy Build. 2020, 209, 109709. [CrossRef]

21. Vera, S.; Pinto, C.; Tabares-Velasco, P.C.; Bustamante, W.; Victorero, F.; Gironás, J.; Bonilla, C.A. Influence of vegetation, substrate, and thermal insulation of an extensive vegetated roof on the thermal performance of retail stores in semiarid and marine climates. Energy Build. 2017, 146, 312-321. [CrossRef]

22. Yang, Y.; Davidson, C.I.; Zhang, J. Evaluation of thermal performance of green roofs via field measurements and hygrothermal simulations. Energy Build. 2021, 237, 110800. [CrossRef]

23. Vertal', M.; Zozulák, M.; Vašková, A.; Korjenic, A. Hygrothermal initial condition for simulation process of green building construction. Energy Build. 2018, 167, 166-176. [CrossRef]

24. Wei, T.; Jim, C.; Chen, A.; Li, X. A random effects model to optimize soil thickness for green-roof thermal benefits in winter Energy Build. 2021, 237, 110827. [CrossRef]

25. Klein, P.M.; Coffman, R. Establishment and performance of an experimental green roof under extreme climatic conditions. Sci. Total Environ. 2015, 512-513, 82-93. [CrossRef] [PubMed]

26. Lee, L.S.; Jim, C. Thermal-irradiance behaviours of subtropical intensive green roof in winter and landscape-soil design implications. Energy Build. 2019, 209, 109692. [CrossRef]

27. Besir, A.B.; Cuce, E. Green roofs and facades: A comprehensive review. Renew. Sustain. Energy Rev. 2018, 82, 915-939. [CrossRef]

28. Zhao, M.; Srebric, J.; Berghage, R.D.; Dressler, K.A. Accumulated snow layer influence on the heat transfer process through green roof assemblies. Build. Environ. 2015, 87, 82-91. [CrossRef]

29. Moody, S.S.; Sailor, D.J. Development and application of a building energy performance metric for green roof systems. Energy Build. 2013, 60, 262-269. [CrossRef]

30. Cascone, S.; Catania, F.; Gagliano, A.; Sciuto, G. A comprehensive study on green roof performance for retrofitting existing buildings. Build. Environ. 2018, 136, 227-239. [CrossRef]

31. Ponechal, R. Increasing thermal mass in low carbon dwelling. Procedia Eng. 2015, 111, 645-651. [CrossRef]

32. Ponechal, R.; Staffenova, D. Impact of external wall insulation thickness on internal surface temperature behavior. In Proceedings of the Matec Web of Conferences, RSP 2017-XXVI R-S-P Seminar 2017 Theoretical Foundation of Civil Engineering, Warsaw, Poland, 21-25 August 2017; Volume 117. [CrossRef]

33. Evins, R.; Dorer, V.; Carmeliet, J. Simulating external longwave radiation exchange for buildings. Energy Build. 2014, 75, 472-482. [CrossRef]

34. Daouas, N. Impact of external longwave radiation on optimum insulation thickness in Tunisian building roofs based on a dynamic analytical model. Appl. Energy 2016, 177, 136-148. [CrossRef]

35. Juras, P.; Jurasova, D. Outdoor Climate Change Analysis in University Campus: Case Study with Heat-Air-Moisture Simulation. Civ. Environ. Eng. 2020, 16, 370-378. [CrossRef]

36. Jurasova, D. Analysis of long-term measured exterior air temperature in Zilina. Civ. Environ. Eng. 2018, 14, 124-131. [CrossRef] 
37. Vertal, M.; Vranayova, Z.; Varga, J.; Poorova, Z.; Vranay, F.; Zozulak, M.; Vargova, A.; Zelenakova, M.; Gregorek, R. Experimentálna vegetačná strecha s biodiverzným potenciálom (in Slovak). Strechy Fasády Izol. 2020, 25-29.

38. Testujeme Zelené Střechy. Available online: https:/ / www.uceeb.cz/aktuality/testujeme-zelene-strechy (accessed on 21 November 2021).

39. Juras, P. Introduction to the Green Roof Research. Lect. Notes Civ. Eng. 2021, 189, 108-115.

40. Štaffenová, D.; Ponechal, R.; Ďurica, P.; Cangár, M. Climate Data Processing for Needs of Energy Analysis. Adv. Mater. Res. 2014, 1041, 129-134. 